\title{
Kompetencje Prezesa Urzędu Regulacii Energetyki na gruncie wybranych regulacii ustawowych
}

\section{The competences of the President of the Energy Regulatory Office on the ground of selected statutory regulations}

\begin{abstract}
Streszczenie: Kompetencje Prezesa Urzędu Regulacji Energetyki są zapisane w pierwszym rzędzie w ustawie z 10 kwietnia 1997 roku Prawo energetyczne (tekst jednolity: Dz.U. z 2012 r., poz. 1059 z późn. zm.). W związku z tym przedstawiona w opracowaniu analiza kompetencji tego podmiotu opiera się przede wszystkim na przepisach prawnych zawartych w tej ustawie. Artykuł nie odnosi się natomiast do czynności realizowanych przez Prezesa Urzędu Regulacji Energetyki w indywidualnych sprawach. Wynika to z głównego celu prowadzonej analizy, którym jest wskazanie zakresu kompetencji Prezesa Urzędu Regulacji Energetyki, wynikającego z obowiązujących rozwiązań prawnych. W pierwszej części artykułu omawiane są kwestie związane z postępowaniem kwalifikacyjnym na stanowisko Prezesa Urzędu Regulacji Energetyki (zob. zwłaszcza art. 21 ust. 2e ustawy Prawo energetyczne). Następnie analizowana jest kompetencja wspomnianego wyżej Prezesa dotycząca udzielania koncesji (prawo do udzielania i cofania przez niego koncesji wynika w szczególności z art. 23 ust. 2 pkt 1 ustawy Prawo energetyczne). W ostatniej części artykułu omawiane są inne wybrane kompetencje Prezesa Urzędu Regulacji Energetyki (zob. na przykład art. 23 ust. 1, ust. 2 pkt 6a, pkt 6b, pkt 10, pkt 16 i pkt 17, art. 24 ust. 1, art. 28 ust. 1, art. 28a ustawy Prawo energetyczne). W podsumowaniu podkreśla się różnorodność kompetencji realizowanych przez wspomnianego wyżej Prezesa.
\end{abstract}

\begin{abstract}
Competences of the President of the Energy Regulatory Office are regulated primarily in the Energetic Law Act of 10th April 1997 (consolidated text: Journal of Laws of 2012, item 1059 with later amendments). In connection with this, the analysis of this subject's competences, presented in this paper, is grounded first of all on the regulations inserted in the aforementioned act. This article, however, does not refer to activities realized by the President of the Energy Regulatory Office in individual cases. It issues from the main aim of the led analysis, which is to present a range of competences of the President of the Energy Regulatory Office, resulting from the binding legal solutions. In the first part of this article, problems connected with qualifying procedure on the position of the President of the Energy Regulatory Office are treated (see especially article 21 item 2e of the Energetic Law Act). Furthermore, the competence of the above-mentioned President referring to granting a concession is analysed (authority to granting and withdrawal of concession in particular results from article 23 item 2 point 1 of the Energetic Law Act). In the last part of this article, other selected competences of the President of the Energy Regulatory Office are treated (see for example article 23 item 1, item 2 point 6a,
\end{abstract}


point $6 \mathrm{~b}$, point 10, point 16 and point 17, article 24 item 1, article 28 item 1, article 28a of the Energetic Law Act). In conclusion, diversity of the aforesaid President's competences is emphasized.

Słowa kluczowe: energia; prawo; przedsiębiorstwo; przemysł

Keywords: energy; law; enterprise; industry

Otrzymano: 7 lutego 2015

Received: 7 February 2015

Zaakceptowano: 3 lipca 2015

Accepted: 3 July 2015

\section{Sugerowana cytacja / Suggested citation:}

Woroniecki, P.M. (2015). Kompetencje Prezesa Urzędu Regulacji Energetyki na gruncie wybranych regulacji ustawowych. Prace Komisji Geografii Przemystu Polskiego Towarzystwa Geograficznego, 29(3), 39-47.

\section{WSTĘP}

Zgodnie z art. 21 ust. 2 ustawy z dnia 10 kwietnia 1997 r. Prawo energetyczne (tekst jednolity: Dz.U. z 2012 r., poz. 1059 z późn. zm.) Prezes Urzędu Regulacji Energetyki to centralny organ administracji rządowej. Odwołując się do poglądów doktryny prawa administracyjnego, trzeba wyjaśnić, że o organie administracji rządowej można mówić wówczas, gdy stanowi on wydzielony element w strukturze administracji rządowej, w swoich działaniach reprezentuje państwo, może sięgać po środki władcze oraz funkcjonuje w granicach powierzonych mu kompetencji (Ochendowski, 1999: 207). W myśl z kolei art. 146 ust. 3 Konstytucji Rzeczypospolitej Polskiej z dnia 2 kwietnia 1997 r. (Dz.U. z 1997 r. Nr 78, poz. 483 z późn. zm.) kierownictwo nad administracją rządową sprawuje Rada Ministrów. W uzupełnieniu do powyższej charakterystyki należy jeszcze dodać, że - jak wskazuje się w literaturze przedmiotu - organ centralny to taki organ, który swoją działalnością obejmuje całe państwo (Ochendowski, 1999: 214).

Działalność Prezesa Urzędu Regulacji Energetyki można rozpatrywać zarówno przez pryzmat faktycznie podejmowanych przez niego działań, jak i od strony prawnej, tzn. badając przyznane mu przez ustawodawcę kompetencje. Przedmiot niniejszego opracowania koncentruje się na tym drugim aspekcie. W artykule nie są natomiast rozpatrywane konkretne działania podejmowane przez osoby piastujące to odpowiedzialne stanowisko, co jest konsekwencją założonego celu, którym jest przedstawienie prawnie ugruntowanego obszaru kompetencji Prezesa Urzędu Regulacji Energetyki. Podstawowym źródłem analizowanych rozwiązań normatywnych jest wspomniana na wstępie ustawa z dnia 10 kwietnia 1997 r. Prawo energetyczne. Ponadto pewne istotne - z punktu widzenia funkcji realizowanych przez Prezesa Urzędu Regulacji Energetyki - regulacje wynikają z ustawy z dnia 2 lipca 2004 r. o swobodzie działalności gospodarczej (tekst jednolity: Dz.U. z 2015 r., poz. 584 z późn. zm.). 


\section{Ustawowe wymogi kwalifikacyjne Prezesa Urzędu Regulacji Energetyki}

Polski ustawodawca stawia wobec osoby ubiegającej się o stanowisko Prezesa Urzędu Regulacji Energetyki dość wysokie wymagania w odniesieniu do posiadanych przez nią kwalifikacji. O ile wymóg legitymowania się przez nią tytułem zawodowym magistra lub równorzędnym, ustanowiony w art. 21 ust. $2 \mathrm{~b}$ pkt 1 ustawy Prawo energetyczne, nie jest być może szczególnie wygórowanym oczekiwaniem, to już wprowadzona do art. 21 ust. 2b pkt 7 tej ustawy konieczność posiadania przez aplikującą osobę wykształcenia i wiedzy związanej ze sprawami należącymi do kompetencji Prezesa Urzędu Regulacji Energetyki pozwala przyjąć, iż na to kluczowe stanowisko będą powoływane osoby posiadające - przynajmniej formalnie - odpowiednie przygotowanie merytoryczne. Oczywiście fakt spełnienia wspomnianych wyżej wymogów musi zostać właściwie zweryfikowany. Zgodnie z art. 21 ust. 2e ustawy Prawo energetyczne obowiązek takiej weryfikacji spoczywa na specjalnym zespole składającym się przynajmniej z trzech członków wybranych przez szefa Kancelarii Prezesa Rady Ministrów, działającym z upoważnienia tego ostatniego, dających - dzięki swojej wiedzy i doświadczeniu - gwarancję wyselekcjonowania najlepszych kandydatów, przy czym prowadząc nabór na wspomniane stanowisko, zespół ocenia kandydata pod kątem posiadanego przez niego doświadczenia zawodowego, wiedzy koniecznej do realizowania obowiązków na tym stanowisku oraz posiadanych kompetencji kierowniczych.

Prowadząc nabór, zespół ma obowiązek wyłonić maksymalnie trzech kandydatów i poinformować o nich szefa Kancelarii Prezesa Rady Ministrów (art. 21 ust. 2h ustawy Prawo energetyczne). Natomiast powołanie Prezesa Urzędu Regulacji Energetyki - spośród kandydatów wybranych w drodze naboru mającego charakter otwarty i konkurencyjny - leży w gestii Prezesa Rady Ministrów, który ma też prawo odwołać Prezesa Urzędu Regulacji Energetyki (art. 21 ust. 2a ustawy Prawo energetyczne). Jednakże, zgodnie z wolą ustawodawcy, to przysługujące premierowi prawo odwołania Prezesa Urzędu Regulacji Energetyki może być przez niego wykonane jeszcze przed końcem kadencji prezesa tegoż urzędu, o ile zachodzi jeden z przypadków określonych w art. 21 ust. 2 m pkt 1 - pkt 5 ustawy Prawo energetyczne. Przy okazji warto wspomnieć, że do kompetencji Prezesa Urzędu Regulacji Energetyki należy powoływanie Wiceprezesa Urzędu Regulacji Energetyki spośród osób, które zostały wyłonione w trakcie naboru o charakterze otwartym i konkurencyjnym, jak również do uprawnień Prezesa Urzędu Regulacji Energetyki należy odwoływanie tegoż wiceprezesa (art. 21 ust. 5 ustawy Prawo energetyczne).

\section{Prezes Urzędu Regulacji Energetyki Jako KOnCESJodawca}

Wśród licznych zadań Prezesa Urzędu Regulacji Energetyki kluczowe miejsce zajmuje udzielanie oraz cofanie przez niego koncesji (art. 23 ust. 2 pkt 1 ustawy Prawo energetyczne). Kwestie związane z realizacją tego zadania są unormowane przede wszystkim w rozdziale piątym (art. 32-art. 50a) ustawy Prawo energetyczne, zatytułowanym „Koncesje i taryfy”.

To, jakiego rodzaju działalność wymaga uzyskania koncesji, wynika z regulacji prawnych. I tak, co do zasady uzyskanie koncesji jest konieczne np. w przypadku wytwarzania tak 
paliw, jak i energii (są tutaj wyjątki), przechowywania paliw gazowych, jeżeli celowi temu służą instalacje magazynowe, poddawania gazu ziemnego w stanie skroplenia procesowi regazyfikacji w obrębie instalacji gazu ziemnego w stanie skroplenia, przechowywania paliw ciekłych (istnieją w tym zakresie pewne wyjątki), przesyłania lub dystrybuowania paliw bądź energii, o ile nie zachodzą wyłączenia, oraz w przypadku dokonywania obrotu, którego przedmiotem są paliwa lub energia, też z pewnymi wyjątkami (art. 32 ust. 1 pkt 1-pkt 4 ustawy Prawo energetyczne). Z kolei w art. 36 ustawy Prawo energetyczne prawodawca określił okres, na jaki udzielana jest koncesja, wynoszący od 10 do 50 lat, o ile jednak przedsiębiorca nie zawnioskował o przyznanie mu koncesji na okres krótszy. Warto jednak w tym miejscu zauważyć, że przedsiębiorstwo energetyczne może zostać zobligowane - już po wygaśnięciu koncesji - przez Prezesa Urzędu Regulacji Energetyki do kontynuowania koncesjonowanej działalności przez maksymalnie 2 lata, o ile jest to konieczne ze względu na interes społeczny (art. 40 ust. 1 ustawy Prawo energetyczne). W takiej sytuacji zabezpieczenie finansowe dla przedsiębiorstwa energetycznego polega na tym, że przysługuje mu pokrycie - ze strony Skarbu Państwa - ewentualnych strat w kwocie, której wysokość ograniczona jest uzasadnionymi kosztami działalności wskazanej w koncesji, z zastrzeżeniem zachowania należytej staranności (art. 40 ust. 2 ustawy Prawo energetyczne).

Polski ustawodawca ściśle określił warunki, jakie musi spełniać podmiot starający się o uzyskanie koncesji. W szczególności musi on mieć do dyspozycji środki finansowe w takiej wysokości, która gwarantuje, że działalność będzie wykonywana w sposób prawidłowy, przy czym wystarczające jest udokumentowanie, że pozyskanie takich środków jest możliwe (art. 33 ust. 1 pkt 2 ustawy Prawo energetyczne). Przykładem innej przesłanki warunkującej uzyskanie koncesji jest wykazanie przez podmiot wnioskujący, iż dysponuje on możliwościami technicznymi gwarantującymi wykonywanie działalności w sposób prawidłowy (art. 33 ust. 1 pkt 3 ustawy Prawo energetyczne).

Wnioskodawca musi się także liczyć z tym, że przydzielenie mu koncesji może zostać uwarunkowane złożeniem przez niego zabezpieczenia majątkowego, którego celem będzie zaspokojenie roszczeń zgłaszanych przez osoby trzecie, których źródłem może być niewłaściwe prowadzenie koncesjonowanej działalności, nie wyłączając szkód powstałych w środowisku (art. 38 ustawy Prawo energetyczne). Natomiast zgodnie z przepisem art. 38a ust. 1 ustawy Prawo energetyczne, jeżeli udzielana koncesja ma opiewać na produkowanie paliw ciekłych (nie dotyczy to gazu płynnego LPG), a także na obrót nimi z zagranicą, wówczas wymagane jest złożenie przez podmiot wnioskujący zabezpieczenia majątkowego na kwotę $10 \mathrm{mln}$ zł po to, aby zabezpieczyć powstałe albo mogące powstać należności związane z prowadzoną działalnością wynikającą z koncesji, z tytułów wymienionych w tym przepisie. W dalszej części wspomnianego wyżej artykułu ustawodawca wymienia formy zabezpieczenia majątkowego, którymi mogą być w szczególności gwarancja bankowa lub ubezpieczeniowa, poręczenie udzielone przez bank, weksel zawierający poręczenie wekslowe banku, czek potwierdzony (o ile potwierdzenie pochodzi od krajowego banku wystawcy czeku), zastaw rejestrowy, którego przedmiotem są prawa z walorów Skarbu Państwa lub Narodowego Banku Polskiego - stosownie do wartości nominalnej tych walorów (art. 38a ust. 3 pkt 1-pkt 5 ustawy Prawo energetyczne). 
Istotnym udogodnieniem wprowadzonym przez ustawodawcę dla podmiotów zamierzających zajmować się prowadzeniem działalności gospodarczej podlegającej koncesjonowaniu, której przedmiotem jest wytwarzanie, przetwarzanie, magazynowanie, przesyłanie, dystrybucja paliw lub energii oraz obrót nimi, skraplanie gazu ziemnego, a także jego regazyfikacja (albo zamierzających zmodyfikować zakres tej działalności), jest to, że mogą one wystąpić o przyznanie im promesy: koncesji bądź zmiany koncesji (art. 43 ust. 1 ustawy Prawo energetyczne). Taka promesa wydawana jest przez Prezesa Urzędu Regulacji Energetyki w formie decyzji administracyjnej (art. 43 ust. 2 ustawy Prawo energetyczne). W tym kontekście warto przypomnieć, że zgodnie z art. 60 ust. 1 zdanie pierwsze ustawy o swobodzie działalności gospodarczej promesa jest przyrzeczeniem wydania koncesji, o które ma prawo ubiegać się przedsiębiorca zamierzający zająć się prowadzeniem działalności gospodarczej wymagającej otrzymania koncesji.

W treści promesy wskazywany jest termin jej ważności, który musi wynosić minimum sześć miesięcy (art. 43 ust. 3 ustawy Prawo energetyczne). Co jednak szczególnie istotne, ustawodawca zakazuje - o ile ważność promesy jeszcze nie wygasła - odmowy udzielenia koncesji dotyczącej prowadzenia działalności określonej w promesie bądź jej zmiany przy założeniu, że nie zmieniły się okoliczności faktyczne lub prawne wyszczególnione we wniosku, na podstawie którego wydano promesę (art. 43 ust. 4 ustawy Prawo energetyczne).

Jeżeli natomiast przedsiębiorstwo energetyczne uzyskało już koncesję w oparciu o przepisy ustawy, to przesłanką jej wygaśnięcia jeszcze przed nadejściem terminu, na który ją przyznano, jest usunięcie wspomnianego przedsiębiorstwa z odpowiedniego rejestru (ewidencji), przy czym wygaśnięcie koncesji następuje w dniu usunięcia podmiotu z tego rejestru bądź ewidencji (art. 42 ustawy Prawo energetyczne).

Ponadto warunki koncesji, która została już wydana, mogą zostać zmienione przez Prezesa Urzędu Regulacji Energetyki, o ile z odpowiednim wnioskiem wystąpi przedsiębiorstwo energetyczne (art. 41 ust. 1 ustawy Prawo energetyczne).

Szczegółowo zostały przez ustawodawcę unormowane przesłanki cofnięcia koncesji. Przede wszystkim, zgodnie z art. 41 ust. 2 pkt 1 ustawy Prawo energetyczne, jest ona cofana przez Prezesa Urzędu Regulacji Energetyki, jeżeli wystąpią okoliczności przewidziane w art. 58 ust. 1 ustawy o swobodzie działalności gospodarczej. Wskazany art. 58 ust. 1 ustawy o swobodzie działalności gospodarczej wymienia (w dwóch punktach) okoliczności uzasadniające cofnięcie koncesji przez organ koncesyjny, które polegają na wydaniu prawomocnego orzeczenia zakazującego przedsiębiorcy prowadzenia działalności gospodarczej przewidzianej w koncesji, niepodjęciu przez przedsiębiorcę w ustanowionym terminie takiej działalności, pomimo dokonania wezwania przez organ koncesyjny (w takim przypadku również następuje cofnięcie koncesji), lub trwałym zaprzestaniu realizowania działalności gospodarczej określonej w koncesji.

Wracając do ustawy Prawo energetyczne, trzeba wspomnieć, że przykładem innej przesłanki uzasadniającej cofnięcie koncesji przez Prezesa Urzędu Regulacji Energetyki jest zmiana - w zakresie wynikającym z ustawy - warunków prowadzonej działalności gospodarczej ujętej w koncesji (art. 41 ust. 2 pkt 3 ustawy Prawo energetyczne). Podobnie wykonywanie przez przedsiębiorstwo energetyczne działalności polegającej na produkcji paliw 
ciekłych bądź obrocie nimi z zagranicą przy braku wniesionego zabezpieczenia majątkowego skutkuje cofnięciem przez Prezesa Urzędu Regulacji Energetyki koncesji na prowadzenie tego rodzaju działalności (art. 41 ust. 2b ustawy Prawo energetyczne).

W pewnych sytuacjach ustawodawca daje Prezesowi Urzędu Regulacji Energetyki wybór sposobu postępowania. Otóż, w myśl art. 41 ust. 3 ustawy Prawo energetyczne, może on cofnąć koncesję albo zmienić jej zakres, jeśli wystąpią okoliczności wymienione w art. 58 ust. 2 ustawy o swobodzie działalności gospodarczej. Wzmiankowany art. 58 ust. 2 ustawy o swobodzie działalności gospodarczej stanowi, w dwóch kolejnych punktach, że okolicznościami obligującymi organ koncesyjny do cofnięcia koncesji lub zmiany jej zakresu jest zachowanie przedsiębiorcy polegające - po pierwsze - na rażącym naruszeniu warunków określonych koncesją lub innych, przewidzianych w przepisach prawa, warunków prowadzenia działalności gospodarczej, na którą uzyskano koncesję, oraz - po drugie - na nieusunięciu we wskazanym terminie stanu faktycznego (ewentualnie prawnego) naruszającego warunki ustalone koncesją lub przepisami normującymi działalność będącą przedmiotem koncesji. To jednak nie wszystko, gdyż art. 41 ust. 4 pkt 1 ustawy Prawo energetyczne daje Prezesowi Urzędu Regulacji Energetyki możliwość cofnięcia koncesji lub dokonania zmiany jej zakresu na skutek zdarzeń wyszczególnionych w art. 58 ust. 3 ustawy o swobodzie działalności gospodarczej. Spośród zdarzeń wymienionych w tymże artykule 58 ust. 3 ustawy o swobodzie działalności gospodarczej, pozwalających organowi koncesyjnemu na cofnięcie koncesji albo zmianę jej zakresu, można przykładowo wskazać te, które polegają na tym, że obronność lub bezpieczeństwo państwa są zagrożone bądź zagrożone jest bezpieczeństwo obywateli. Trzeba też dodać, że - w myśl art. 41 ust. 4 pkt 2 ustawy Prawo energetyczne - przysługująca Prezesowi Urzędu Regulacji Energetyki możliwość cofnięcia koncesji lub zmiany jej zakresu występuje, gdy przedsiębiorstwo energetyczne ulega podziałowi lub łączą się z nim inne podmioty.

\section{Inne wybrane kompetencje Prezesa Urzędu Regulacji Energetyki}

Bardzo ważna kompetencja Prezesa Urzędu Regulacji Energetyki polega na regulowaniu działalności przedsiębiorstw energetycznych stosownie do przepisów ustawy i polityki energetycznej państwa, dążąc do tego, aby interesy przedsiębiorstw energetycznych oraz podmiotów odbierających paliwa i energię były zrównoważone (art. 23 ust. 1 ustawy Prawo energetyczne).

Kolejna sprawa, na którą trzeba zwrócić uwagę, związana jest z polityką energetyczną, która to polityka musi być brana pod uwagę przez Prezesa Urzędu Regulacji Energetyki (zob. powołany wyżej art. 23 ust. 1 ustawy Prawo energetyczne). Jako cel tej polityki art. 13 ustawy Prawo energetyczne wskazuje ,zapewnienie bezpieczeństwa energetycznego kraju, wzrostu konkurencyjności gospodarki i jej efektywności energetycznej, a także ochrony środowiska". Trafnie podkreśla się w literaturze przedmiotu, że dopracowana i efektywna polityka energetyczna wraz z rozwiniętym przemysłem energetycznym stanowią niezbędny fundament do tego, aby ambicje Polaków, dotyczące uzyskania przez nasz kraj pozycji 
najbardziej liczącego się gracza na wschodnim obszarze Unii Europejskiej, mogły zostać urzeczywistnione (Nowak, 2009: 185).

W polityce energetycznej państwa powinny znaleźć się informacje przykładowo o bilansie paliwowo-energetycznym kraju, zdolnościach wytwórczych cechujących krajowe źródła paliw oraz energii, zdolnościach przesyłowych (włączając w to połączenia międzynarodowe), efektywności energetycznej gospodarki, działaniach związanych z ochroną środowiska, rozwoju wykorzystania instalacji związanej z odnawialnym źródłem energii, rozmiarach i rodzajach zapasów paliw (art. 14 pkt 1-pkt 7 ustawy Prawo energetyczne). W kontekście wspomnianej wyżej kwestii dotyczącej odnawialnych źródeł energii należy w pełni podzielić wyrażone w literaturze przedmiotu stanowisko, że rozwój energetyki odnawialnej oraz wzrost jej znaczenia w łącznym bilansie energetycznym to czynniki warunkujące powodzenie aktualnie prowadzonej w ramach Unii Europejskiej polityki energetycznej, która w szczególności zmierza do zapewnienia państwom wchodzącym w jej skład bezpieczeństwa energetycznego, jak również uwzględnia kwestie dotyczące ochrony środowiska (Izbicki, 2012: 369).

Ustawodawca, podkreślając, że zrównoważony rozwój kraju to zasada, w oparciu o którą przygotowuje się politykę energetyczną państwa, wyodrębnił jednocześnie trzy zasadnicze elementy tej polityki, którymi są - po pierwsze - ocena tego, jak polityka energetyczna państwa była realizowana w poprzednim okresie, po drugie - prognoza sporządzana na okres przynajmniej dwudziestoletni oraz - po trzecie - program przewidujący działania wykonawcze na okres czteroletni z wyszczególnieniem instrumentów jego realizacji (art. 15 ust. 1 pkt 1-pkt 3 ustawy Prawo energetyczne).

Ponadto prawodawca nakłada - w art. 24 ust. 1 ustawy Prawo energetyczne - na Prezesa Urzędu Regulacji Energetyki obowiązek polegający na tym, że podmiot ten „składa ministrowi właściwemu do spraw energii corocznie, w terminie do dnia 30 kwietnia każdego roku, sprawozdanie ze swojej działalności, w tym ocenę bezpieczeństwa dostarczania paliw gazowych i energii elektrycznej, stosownie do zakresu działania określonego w art. 23 ust. 2, oraz przedstawia, na jego żądanie, informacje z zakresu swojej działalności”. W art. 23 ust. 2 ustawy Prawo energetyczne ustawodawca powierza Prezesowi Urzędu Regulacji Energetyki wiele istotnych kompetencji, wśród których można wymienić przykładowo te polegające na przyznawaniu certyfikatów niezależności, określaniu i publikowaniu różnych wskaźników, nie wyłączając cen o charakterze wskaźnikowym, ważnych w procedurze opracowywania taryf, publikowaniu informacji pomagających zwiększyć efektywność korzystania z paliw oraz energii (art. 23 ust. 2 pkt 6a, pkt 16 i pkt 17 rzeczonej ustawy).

Na koniec prezentacji kompetencji Prezesa Urzędu Regulacji Energetyki trzeba też wspomnieć o bardzo istotnej ich kategorii, a mianowicie o jego kompetencjach weryfikacyjnych. Uprawnienia te polegają np. na możliwości sprawowania kontroli nad standardami jakościowymi w zakresie obsługi odbiorców oraz na sprawdzaniu na skutek wniosku odbiorcy, czy paliwa gazowe i energia elektryczna spełniają parametry jakościowe (art. 23 ust. 2 pkt 10 ustawy Prawo energetyczne). Ponadto - jak stanowi art. 23 ust. 2 pkt 6 b ustawy Prawo energetyczne - wspomniany prezes kontroluje, czy właściciel sieci przesyłowej i operator systemu przesyłowego gazu spełniają obowiązki wyszczególnione w ustawie Prawo energetyczne i w umowie wymienionej w art. 9h ust. 3 pkt 2 tej ustawy, jak też monitoruje powiązania 
łączące właściciela sieci przesyłowej i operatora systemu przesyłowego oraz występujący między nimi przepływ informacji.

Realizując swoje kompetencje weryfikacyjne, Prezes Urzędu Regulacji Energetyki może przeglądać księgi rachunkowe prowadzone przez przedsiębiorstwo energetyczne, jak również może się do niego zwrócić z żądaniem przedstawienia informacji związanych z prowadzoną przez ten podmiot działalnością gospodarczą, nie wyłączając informacji na temat projektów inwestycyjnych tego podmiotu, przy zachowaniu jednak przepisów odnoszących się do ochrony informacji niejawnych oraz innych informacji podlegających prawnej ochronie (art. 28 ust. 1 ustawy Prawo energetyczne). Co więcej, na organ kontrolujący przedsiębiorstwo energetyczne został nałożony obowiązek informowania Prezesa Urzędu Regulacji Energetyki o odkrytych przekroczeniach prawa, które można by zakwalifikować jako naruszenie warunków prowadzenia działalności przewidzianych koncesją lub przepisami normującymi działalność gospodarczą ujętą w koncesji, za wyjątkiem informacji, co do otrzymywania których rzeczony prezes nie ma uprawnień (art. 28a ustawy Prawo energetyczne).

\section{Podsumowanie}

Prezes Urzędu Regulacji Energetyki posiada bardzo liczne kompetencje wynikające z ustawy z dnia 10 kwietnia 1997 r. Prawo energetyczne. Jednocześnie kompetencje te mają zróżnicowany charakter. Po pierwsze, jest on podmiotem odpowiedzialnym za wydawanie i cofanie koncesji (art. 23 ust. 2 pkt 1 ustawy Prawo energetyczne). Ustawodawca bardzo szczegółowo unormował w rozdziale piątym ustawy Prawo energetyczne większość spraw związanych z realizacją tej kompetencji przez Prezesa Urzędu Regulacji Energetyki (zob. art. 32 i następne tej ustawy). Ze względu na wagę tego uprawnienia dla ogromnej liczby uczestników życia gospodarczego rozwiązanie takie należy uznać za w pełni uzasadnione.

Po drugie, Prezes Urzędu Regulacji Energetyki realizuje wiele innych kompetencji, w tym o charakterze weryfikacyjnym (zob. np. art. 23 ust. 2 pkt 6 b i pkt 10 ustawy Prawo energetyczne). Fakt przyznania mu kompetencji weryfikacyjnych również trzeba ocenić pozytywnie. Kompetencje te pozwalają mu bowiem m.in. na sprawdzanie, czy np.właściciel sieci przesyłowej odpowiednio wywiązuje się ze swoich obowiązków (zob. art. 23 ust. 2 pkt 6b ustawy Prawo energetyczne).

\section{Literatura \\ References}

Izbicki, M. (2012). System wsparcia rozwoju odnawialnych źródeł energii w Polsce. W: A. Walaszek-Pyzioł (red.). Wybrane węzłowe zagadnienia współczesnego prawa energetycznego. Kraków: At Wydawnictwo, 369-380.

Konstytucja Rzeczypospolitej Polskiej z dnia 2 kwietnia 1997 r. (Dz.U. z 1997 r. Nr 78, poz. 483 z późn. zm.).

Nowak, B. (2009). Wewnętrzny rynek energii w Unii Europejskiej. Studium porównawcze na podstawie sektorów energii elektrycznej i gazu a sprawa (kwestia) Polski. Warszawa: Wydawnictwo C.H. Beck. 
Ochendowski, E. (1999). Prawo administracyjne. Część ogólna. Toruń: Towarzystwo Naukowe Organizacji i Kierownictwa „Dom Organizatora”.

Ustawa z dnia 10 kwietnia 1997 r. Prawo energetyczne (tekst jednolity: Dz.U. z 2012 r., poz. 1059 z późn. zm.).

Ustawa z dnia 2 lipca 2004 r. o swobodzie działalności gospodarczej (tekst jednolity: Dz.U. z 2015 r., poz. 584 z późn. zm.).

Paweł Marek Woroniecki, doktor nauk prawnych, Uniwersytet Jagielloński, Wydział Prawa i Administracji, Katedra Polityki Gospodarczej. W pracy naukowej zajmuje się zagadnieniami dotyczącymi w szczególności prawa budżetowego, analizuje również rozwiązania prawne determinujące sytuację przedsiębiorców w różnych sektorach gospodarki oraz bada - na płaszczyźnie prawnej - działalność wybranych instytucji należących do sfery administracji publicznej.

Pawel Marek Woroniecki, doctor of legal science, the Jagiellonian University, Faculty of Law and Administration, Chair of Economic Policy. In his research work deals with problems concerning in particular budget law, he also analyses legal solutions determining a situation of entrepreneurs in various sectors of economy and he makes - on a legal plane - researches of activity of selected institutions belonging to a sphere of public administration.

\section{Adres/address:}

Uniwersytet Jagielloński

Wydział Prawa i Administracji

Katedra Polityki Gospodarczej

ul. Bracka 12, 31-005 Kraków, Polska

e-mail: pawel.woroniecki@uj.edu.pl 